\title{
Hyperlexikon jako pozvání k reflexi problémů literární vědy
}

\author{
Petr Kučera (PIzeň)
}

Roman Mikuláš et al.: Literaturwissenschaft in internationaler Perspektive. [Literární věda v mezinárodní perspektivě] Nümbrecht: Kirsch-Verlag, 2019. 510 s. ISBN 978-3-943906-35-6.

Roman Mikuláš a kol.: Podoby literárnej vedy: Teórie - Metódy - Smery. Bratislava: VEDA, 2016. 350 s. ISBN 978-80-224-1524-8.

Kolektivní dílo badatelů působících v bratislavském Ústavu svetovej literatúry SAV, na slovenských a dalších (středo)evropských univerzitách se koncepcí, rozsahem a interdisciplinárními přesahy vymyká $\mathrm{z}$ produkce literárněvědných monografí́. Ve dvaatřiceti heslech rozdělených do tři skupin je představeno - vedle disciplín, jejichž tradice sahá až do antiky - mnohé z hledání současné literární vědy, která se často vzdaluje svému filologickému jádru, nově definuje svůj předmět a metodologicky se inspiruje nejen vědami humanitními a sociálními, ale i př́rodními. Monografie si klade explicitně za cíl odhalovat proces konstituování literární vědy jako interdisciplinární, resp. transdisciplinární, postupně se diferencující na více úrovních, čemuž odpovídají pojmy označující aspekty literárních textů, ale i pojmy literárněvědného metadiskurzu.

Úvodní blok tradičních filologických a literárně teoretických disciplín (Poetika, Rétorika, Genológia, Štylistika, Verzológia, Metrika) zpracoval Tibor Žilka jako výklad pojmů a kategorií, na který navazuje problémově pojatá reflexe současného stavu př́slušné disciplíny. Z každého textu je zřejmé, že ho psal klasik nitranské školy literární komunikace - logická struktura kategoriálního myšlení a formulační přesnost jdou ruku v ruce s jasností výkladu. V popředí stojí tradice slovenské literární vědy, zkrátka však nepřišly ani př́inosy českého myšlení (Jan Mukařovský, Lubomír Doležel, Miroslav Červenka, Ivo Pospíšil ad.) v širším mezinárodním kontextu. V duchu nitranské tradice chápe T. Žilka současnou poetiku - tzv. komunikační poetiku - jako disciplínu, která vede intenzivní dialog jednak s teorií komunikace, jednak s lingvistickou teorií textu, čímž výrazně prohlubuje dosavadní zaměření poetiky historické a deskriptivní.

Druhý oddíl mapuje v třinácti heslech hlavní směry literárněvědného myšlení od konce 19. století do současnosti s důrazem na přístupy interdisciplinárně nosné a ve výzkumné praxi bohatě využívané. V kapitole Literárna hermeneu tika sleduje Roman Mikuláš proměny moderní hermeneutiky od Friedricha Schleiermachera přes modernizační impulzy Wilhelma Diltheye k reflexi základního problému hermeneutiky, tj. transformaci souvislosti významů $\mathrm{z}$ jiného světa do světa vlastního v pracích Hanse Georga Gadamera. Těžištěm kapitoly je Gadamerova filosofická hermeneutika, zažívající v současné době (především v německojazyčném prostředí) pozoruhodný rozkvět. R. Mikuláš nepřistupuje $\mathrm{k}$ této podobě hermeneutiky nekriticky - upozorňuje např. na nekonsekventnost Gadamerova chápání porozumění jako aktivního procesu, v němž smysl díla roste v dějinách jeho působení, zároveň však předpokládá, že dílo je ukotvené v tradici, která je daná předem, a proto zůstává neproblematizovaná, resp. předpokládá její bezpodmínečnou platnost.

V kapitole Pozitivistická literární věda se Roman Mikuláš zaměřuje jak na epistemologické premisy pozitivismu, které se prosadily především v obecné historiografii, v literárním dějepisectví pak v pracích Hippolyta Taina, Wilhelma Scherera či Ericha Schmidta, tak i na pozůstatky tohoto směru vědeckého myšlení v současných literárněvědných výzkumech - v teorii a dějinách 
recepce, zejména s ohledem na funkce čtenáře a působení čtenářského publika na tvorbu vkusu a názorů.

Důkladně a s širokým rozhledem po nejnovější světové produkci pojali Róbert Gáfrik a Miloš Zelenka kapitolu Literárni komparatisti$k a$. Autoři nestraní žádnému z proudů srovnávacího myšlení, nezamlčují existenci některých přístupů a usilují o pregnantní výklad hlavních myšlenek teoretiků, jejichž díla jsou často redukována na nepř́lišs srozumitelné teze. Vedle francouzských, amerických, německých, italských či ruských komparatistů věnují autoři náležitou pozornost slovenskému a českému vkladu k mezinárodní debatě (Frank Wollman, Dionýz Ďurišin ad.). Tato kapitola monografie může sloužit zájemcům z různých oborů jako uvedení do živé disciplíny, která představuje alternativu k národním filologiím a ve svém intermediálním směřování zasahuje i do dalších druhů umění, ale také do rozmanitých forem sociální komunikace.

V kapitole Tematológia se Miroslava Režná zabývá metodologickým přínosem literárně sémiotických výzkumů tartusko-moskevské školy (Jurij M. Lotman), bádání Michaila M. Bachtina a analýzám francouzské tematické kritiky (Georges Poulet a Gaston Bachelard). Autorka podává přehled klasifikací témat (Claudio Guillén, Phillipe Chardin, Siegbert Salomon Prawer ad.) a seznamuje čtenáře mj. i s topologickým výzkumem pražské tematologické školy (Daniela Hodrová, Vladimír Macura, Marie Kubínová, Zdeněk Hrbata aj.).

Dejiny ducha je název kapitoly, v níž Roman Mikuláš kontrastuje duchovědný směr v myšlení o literatuře s dřivějším pozitivismem, jehož diferenciaci vědních disciplín se snaží překonat odhalením kulturních procesů jako projevů celostního ducha, z něhož jednotlivé vědní disciplíny vyrostly. Autor připomíná mnohdy opomíjený fakt, že dějiny ducha získaly akcentováním duchovního principu umění společenskou relevantnost, kterou pozitivistická filologie začala na počátku dvacátého století ztrácet.

Heslo Fenomenologická literárna veda (Ladislav Šimon) podává stručný výčet představitelů fenomenologického př́istupu k literárnímu dílu.
Na základě popisu díla Romana Ingardena Das literarische Kunstwerk (1931) zpracovaného Miroslavem Procházkou jako heslo v českém kolektivním Privodci po literárni teorii (1988) charakterizuje Šimon přínos polského myslitele evropské estetice a literární teorii. Škoda, že stranou pozornosti zůstaly práce žáka Edmunda Husserla a významného fenomenologického filosofa dvacátého století Jana Patočky o literatuře a umění.

Kapitola Ruský formalismus Soni Paštekové nastiňuje vlivnou metodu literárněvědné práce, která poskytla impulzy pozdějšímu strukturalismu, jako mnohovrstevný a diferencovaný fenomén. Vedle přínosu Jurije Tyňanova, Borise Tomaševského či Viktora Žirmunského věnuje pozornost Pražskému lingvistickému kroužku, zejména pracím Romana Jakobsona v době jeho československého i amerického exilu. Kromě českých a slovenských snah o rozvíjení formalistické metody je připomenuto také úsilí amerických a francouzských strukturalistů, jakož i výzkumy moskevsko-tartuské školy.

Přehledně pojednal o všech hlavních podobách strukturálního estetického myšlení Pavel Matejovič v kapitole Štrukturalizmus a postštrukturalizmus. Od Saussurova binárního modelu jazykového znaku a zaměření na jazyk u ruských formalistů přechází autor k francouzskému strukturalismu a poststrukturalismu, jehož důraz na dynamickou povahu struktury klade do souvislosti s dřívějším českým strukturalismem. Závěr kapitoly je věnován strukturalistickým východiskům v myšlení slovenských teoretiků.

V kapitole Recepčná estetika seznamuje Roman Mikuláš čtenáře $\mathrm{s}$ konceptem dějin recepce Hanse Roberta Jauße jako aplikací dějin působení Hans-Georga Gadamera a poukazuje na myšlenky Jana Mukařovského o estetické hodnotě literárních děl, z nichž Jauß čerpal. Pouze letmo a obecně je zmíněn český strukturalista Felix Vodička, jehož úvahy o estetickém objektu a dobové čtenářské konkretizaci díla sehrály v debatách o recepci literárních děl nezanedbatelnou roli (blíže k Vodičkovu př́nosu srov. práce rakouského komparatisty českého původu Petra Václava Zimy). Dále si R. Mikuláš všímá z fenomenologie textu vycházející estetiku působení Wolfganga 
Isera (připomíná Iserovo převzetí Ingardenovy kategorie míst nedourčenosti) i sémioticky fundovaného př́stupu strukturalisty Jonathana Cullera.

Problémům a kategoriím sociologie literární produkce, sociologie literárního díla, sociologie literární recepce a sociologie literárního pole je věnována přehledově a v evropských souvislostech koncipovaná kapitola Literárna sociológia a sociológia literatúry Andrey Mikulášové. Autorka upozorňuje mj. na často přehlíženou skutečnost, že literární sociologie se nezabývá pouze obsahem literatury (jak tvrdí kritikové sociologického přístupu k literatuře) a připomíná pokus Georga Lukácse o vytvoření tzv. sociologie literárních forem. Jako příklad literární sociologie, která nemarginalizuje estetické aspekty literatury, je dále nastíněna teorie literárního pole Pierra Bourdieua, podle níž představuje estetická výjimečnost sociální postoj, jímž autor díla indikuje svou pozici v systému literatury a tím i svůj postoj ke společnosti.

Převážně výčtem je krátké heslo Ladislava Šimona Kritika ideológie. Lze jen litovat, že nebyla věnována větší pozornost pracím představitelů kritické teorie, z nichž ve středoevropském kontextu někteří sehráli poměrně důležitou roli (srov. např. české překlady Adornových a Benjaminových studií či monografii Adama Bžocha o W. Benjaminovi, práce Petra V. Zimy o komparatistice a literární moderně ad.).

Vztahem literárních textů $\mathrm{k}$ novým způsobům reprezentace a vnímání obsahů se v širších mezinárodních a mezioborových souvislostech podrobně zabývá kapitola Analýza diskurzu Andrey Mikulášové a Romana Mikuláše. Autoři upozorňují, že v humanitních vědách se analýza diskurzu aplikuje primárně na analýzu historické konstruovanosti poznání, čímž tento teoretický koncept kongruuje hlavně s orientací sociálních věd a v literární vědě se často řadí $\mathrm{k}$ nehermeneutickým tendencím.

Všestranně a problémově pojal kapitolu Semiotika a literárna veda Kristián Benyovszky. V kontrastu k binárnímu konceptu jazykového znaku Ferdinanda de Saussura je hlavní pozornost věnována triadické teorii znaku, který na bázi filosofické logiky vytvořil Charles Sanders Peirce. Vyšší míra abstraktnosti a zprostředkovanosti činí tuto teorii otevřenější rozmanitým aplikacím a dalšímu rozvíjení, což Benyovszky dokládá v celosvětovém kontextu, neopomíjí však ani literárněvědně orientované přínosy středoevropské (zejména české, slovenské a mad’arské).

Závěrečnou část monografie uvozuje kapitola Lubomíra Plesníka a Romana Mikuláše Literár na komunikácia. Významný představitel nitranské školy zde spolu s hlavním autorem monografie pregnantně charakterizují hlavní principy komunikačního př́stupu k literárnímu dílu. Přibližují mj. Antonem Popovičem rozvinutý koncept literární metakomunikace, jakož i ontologicky fundovaný koncept recepčního bytí díla Františka Mika, který - v návaznosti na myšlenky Johna Deweye Art as Experience (1934) - umožňuje chápat literární dílo jako proces probíhající ve vědomí účastníků komunikace, tj. jako ve vědomí zvýznamnělou, a tedy recipovanou danost. Autoři sledují slovenské teoretické impulzy v mezinárodním kontextu, zejména ve vztahu k teorii literárních komunikačních aktů Siegfrieda J. Schmidta.

Také v následujících kapitolách Naratológia (Zuzana Malinovská), Intertextualita (Ján Jambor) a Translatológia (Marián Andričík) přicházejí ke slovu disciplíny, v nichž je slovenská věda tradičně silná. Kapitola Naratológia akcentuje intermediální, inter/trans/pluridisciplinární zaměření původně literárně teoretické disciplíny (teorie vyprávění). Od důkladného představení klasické francouzské strukturalistické naratologie (s připomenutím návazností na ruské formalisty a německé „přednaratologické“ teoretiky vyprávění) postupuje Z. Malinovská k americkým, dalším evropským a k izraelským naratologům, kteří si osvojili terminologii Gérarda Genetta, naplňují však některé pojmy odlišným obsahem. Závěr kapitoly poukazuje na rostoucí význam naratologie jako pluridisciplinární platformy propojující výzkum nejen literárních, ale také neuměleckých textů a přirozeného narativu.

Ján Jambor přechází v kapitole Intertextualita po reflexi hlavních vymezení významové šíře pojmu k historickému nástinu myšlení o fenoménu 
intertextuality, jehož zrod je spojen s teorií dialogičnosti Michaila M. Bachtina a jejím sémioticky založeným rozšířením v pracích Julie Kristevy (představa „univerza textů“, v němž jednotlivé texty odkazují v principu ke všem ostatním textům). Radikálně poststrukturalistické koncepty intertextuality ve francouzské a americké literární vědě uvádí J. Jambor jako impuls ke kritickým reakcím z pozic strukturalismu a hermeneutiky, které vedly ve Francii a v Německu ke vzniku konzervativních konceptů. Dále je charakterizován koncept forem a funkcí mezitextových vztahů Gérarda Genetta jako nejvlivnější strukturalisticko-hermeneutická teorie intertextuality, jakož i pokusy Harolda Blooma a Renaty Lachmann o sblížení poststrukturalistických a strukturalisticko-hermeneutických koncepcí. Závěr kapitoly je věnován stručnému přehledu výzkumu fenoménu intertextuality ve slovenské a české literární vědě.

Kapitola Translatológia Mariána Andričíka seznamuje čtenáře s hlavními pojmy a kategoriemi obecné teorie překladu a tlumočení a podává přehled základních translatologických disciplín a subdisciplín podle Edity Gromové, která navazuje na Antona Popoviče.

Soňa Pašteková se v kapitole Historiografia literatúry zaměřuje především na současnou mezinárodní debatu o problému hledání nového metodologického paradigmatu literární historiografie. Jako modely, které by mohly překonat krizi metodologie a skeptické postoje k tradičním postupům literárního dějepisectví (aditivní a chronologický model), jsou prezentovány koncepty kulturních (areálových) dějin, komparativních dějin, dějin literárních kánonů, nově koncipované literární lexikony a flexibilní model internetových (hypertextových) dějin literatury. Do širšího mezinárodního kontextu jsou zasazeny diskuse českých a slovenských literárních vědců, kteří pocitují intenzivní potřebu vytvoření polyfunkčního modelu utváření vědomí o minulosti. Jana Cviková zpracovala podrobně kapitolu Feministická literárna veda a rodové štúdiá v literárnej vede. Orientovala se převážně na německojazyčné prostředí, v němž probíhá feministický diskurs sice s jistým zpožděním oproti prostředí anglosaskému, avšak intenzivně a podnětně (americké a francouzské podněty jsou stručně zmíněny). Důležitý je seriózní, abstraktním aktivismem nedeformovaný přístup autorky, která literárněvědný výzkum využívající rod jako analytickou kategorii chápe jako množství otevřených a proměnlivých přístupů, v nichž označení disciplíny vyžaduje kontextově podmíněnou sebereflexi a konkrétní konceptualizaci. Světový kontext v následujícím slovenském překladu textu přednášky Anny Babky (proslovené v roce 2015 v Ústavu svetovej literatúry SAV) doplňuje kapitolu J. Cvikové o reflexi problémů souvisejících s kategoriemi užívanými v anglosaském prostředí.

V závěrečných šesti kratších kapitolách podává Roman Mikuláš přehled aplikace konstruktivismu, teorie systémů, empirismu, analytické filosofie, kognitivní vědy a teorie chaosu v literárněvědném bádání. Jde o snahy navázat komunikaci s vědními disciplínami, které patří ke skupině exaktních, technických či přírodních věd. Podobně jako němečtí a někteří další badatelé označuje i R. Mikuláš uvedené snahy jako „konštruktivistická literárna veda“, „systémovoteoretická literárna veda“, „kognitívna literárna veda“ atd. Ne vždy však usilují tyto impulzy o poznávání literárních děl, mnohdy je zajímá komunikace mimoliterární či procesy, které se slovesnou tvorbou souvisejí dosti volně. Zařazení těchto hesel je však v dnešní době žádoucí, nebot' upozorňují na nutnost vykročit ze zaběhaných koridorů filologické teorie a praxe a směřovat $\mathrm{k}$ literární vědě, která by se mohla stát vědou dialogickou.

Monografie Podoby literárnej vedy nabízí všestranný vhled do komplexní problematiky teorie a metodologie literární vědy. Sumarizuje hlavní poznatky a koncepty tradičních i nových disciplín ve světovém kontextu a zachycuje vždy také současnou mezinárodní debatu k příslušné problematice zpo̊sobem, který může být inspirativní nejen pro teoretiky, pedagogy, doktorandy apod. z filologických, ale i z uměnovědných, humanitních, sociálně vědních a dalších disciplín. Zároveň přibližuje přínosy slovenských, ale i českých vědců. Dílo podobného zaměření 
ve středoevropském kontextu v současné době není k dispozici.

Německá verze monografie s názvem Literaturwissenschaft in internationaler Perspektive, který klade důraz na mezinárodní diskusi, není jen překladem výkladových textů původní slovenské publikace - německojazyčným čtenářům nabízí německé překlady ukázek ze slovenských literárních textů a v řadě př́padů také stylisticky upravené či pojmoslovně zpřesněné výkladové pasáže. Vydání monografie v německém jazykovém prostředí lze přivítat jako důležitý počin na poli vědecké a kulturní diplomacie - stačí připomenout, že právě díky německým vydáním, po nichž následovala vydání v dalších jazycích, se např. práce Jana Mukařovského, Miroslava Červenky či Dionýze Ďurišina staly samožrejmou součástí mezinárodní debaty.

\section{doc. PhDr. Petr Kučera, Ph.D.}

Katedra germanistiky a slavistiky

Filozofická fakulta, Západočeská univerzita

Riegrova 11, 30614 Plzeň, Česká republika

pekucera@kgs.zcu.cz 